\title{
Environmentální vzdělání - pokus o systematické pojmenování problému
}

\author{
Jana Dlouhá \\ Envigogika 2006/I/1 - Recenzované články/ Reviewed Papers \\ Publikováno/Published 12. 12. 2006 \\ DOI: http://dx.doi.org/10.14712/18023061.7
}

\begin{abstract}
Abstrakt:
Stručné uvedení do některých významných současných filozoficky a pedagogicky založených diskuzí o problematice environmentálního vzdělávání; v současné době jde především o hledání dostupných řešení $v$ rovině rekonstrukce dominantních sociálně založených "rámcü". Obecný prínos pedagogiky tohoto typu však spočívá spíše v odklonu od systémově založených "ekologizujících" směrů. „Přidanou hodnotu" environmentálně orientovaného myšlení Ize nalézt spiśe v př́stupu kladoucím důraz na vzájemnou závislost, možnost existence ve vztazích; a dále v podpoře kontextuálního vnímání skutečnosti. Tyto nové kvality by mohly zásadním způsobem proměnit vzdělávací cíle, obsahy i metody.
\end{abstract}

\section{Klíčová slova:}

Kritické kurikulum, konstruktivismus, systémové teorie a ekologické př́stupy, kontextové vnímání reality

\begin{abstract}
:
The article attempts to introduce major contemporary environmentally oriented philosophical and pedagogical achievements; shortly reviews problems (experienced within these areas) that include cognitive incompatibility between modern science and the essentially contextual character of the environment. Current practical solutions involve combination of different discourses (and application of language game theories); they do no attempt to intervene in the ontological character of modern knowledge. Critical curricula based on deconstruction of dominant social frames are frequently emphasised as a way out of this situation; on the other hand, transformation of the epistemological field is also demanded. Despite evident (and perhaps necessary) uncertainties, a specific "added value" appearing as an environmental interdependence should be introduced into educational contents, goals and methods related to the environment.
\end{abstract}

\section{Key words:}

Critical curriculum, constructivism, system theories and ecological approaches, contextual perception of reality 


\section{Úvod}

Současné debaty o environmentálním vzdělání se celosvětově vedou převážně $v$ rovině pedagogické a filozofické, $v$ rámci těchto oborových okruhů (diskurzů) na poměrně značně vysoké teoretické úrovni. Zaměřují se na odbornou polemiku s prakticky orientovanými požadavky politik udržitelného rozvoje, nároky ekologicky fundovaných environmentalistů či imperativy "prostého rozumu", které společně deklarují potřebu nápravy "světa" a pokládají vzdělání za prostředek dosažení takto formulovaných cílů. Polemika je kritická, i když často ony externí požadavky uznává - pedagogické př́ístupy se však zcela přirozeně brání instrumentálnímu pojetí vzdělání a považují tyto vnější diskurzy ve svém okruhu působnosti za cizí (Gough, \& Scott, 2004).

"Transformace" vzdělávacích metod, cílů a obsahů je dnes hlavním tématem široce pojatých debat o dalším rozvoji vzdělání, a to nejen environmentálně orientovaného. Souvisí to $s$ celkovou proměnou pedagogických východisek (mění se povaha vědění, role vědy, charakter informačního prostředí atd.) i "výstupư" - člověka jako vzdělávacího "produktu", obecně hodnoty či funkce vzdělanosti z pohledu sociologického. S ohledem na praxi se ukazuje, že současné poznání, které je výsledkem duchovního rozvoje euroamerické civilizace, stále častěji selhává ve vztahu $\mathrm{k}$ problémům, před nimiž právě ona stojí. Nepředvídatelné chování (přírodních) systémů nabývá stále větších rozměrů, přičemž $\mathrm{k}$ jeho regulaci nejsme vybaveni ani teoreticky. To souvisí s komplexní povahou těchto systémů, složitým uspořádáním biosféry a jejích (životně důležitých) funkcí. Interakce př́rodního prostředí se systémy antropogenními jsou pak charakterizovány zvýšenou mírou rizika a tzv. neurčitosti (uncertainty). Právě neurčitost byla $v$ posledních deseti letech identifikována jako hlavní rys environmentálních změn (Berkhout, Leach \& Scoones, 2003) - znamená, že při sebelepší snaze o předvídání procesů, jež v prostředí probíhají, a také managementu, péči o jejich důsledky, nejsme nad nimi schopni převzít plnou kontrolu.

Výše popsaná zkušenost má vliv na proměnu role vědy - nejenže jí nastartovaný rozvoj techniky nese odpovědnost za evidentní vyřazení regulačních "mechanismü" prírody, navíc se ukazuje, že věda není vždy schopna pružně a spolehlivě předkládat návody na nápravu takto vznikajících poruch. Tam, kde ekosystémové "služby" zajištující rovnováhu nevyzpytatelných sil př́rody selhávají, neexistuje adekvátní náhrada člověkem zkonstruovaná, umělá (Alacamo, 2003). Je pak nutno počítat s různými druhy výkyvů, které mají významné přesahy do oblasti sociální.

$\mathrm{S}$ ohledem na adaptaci člověka $\mathrm{k}$ těmto situacím bude jistě nezbytné přizpůsobit také klasické vzdělávací systémy a koncepty, které jsou zatím nastaveny na situace stabilní, rozumem ovladatelné (Atkinson, 2000). V současné době komplexně provázaných vztahů a proměn, které svým tempem několikanásobně zasáhnou každou generaci, nedokáže už vzdělání založit prostou orientaci ve složitosti světa (Barnett, 2000). Pokud pouze učí, jak vytvářet a užívat předvídatelné životní okolnosti, vytváří falešnou iluzi jistot.

\section{Všeobecné proměny myšlení}

Do obecných diskuzí o vzdělání vstupují environmentální discipliny se svým požadavkem na zásadní proměnu základních východisek i vzdělávacích cílü. Společným jmenovatelem těchto snah je ohled na prostředí - a to nikoliv jako objekt manipulace, ale naopak cosi, co je zde (a mělo by být takto zachováno) samo o sobě, nezávisle na jakémkoli racionálně vedeném úsilí. Je to jakési společné „podvědomí" objektivního světa, které vystupuje na povrch právě, když je nerespektováno, potlačováno. Jeho vztahová, kontextuální, pro objektivní pohled neviditelná podstata se ukazuje, až když jsou vztahy jím nesené vážně narušeny. Škody, které vznikají, jsou tak zjevné, že se projevují na reálných předmětech a často je Ize sledovat zpět až k bodu jejich vzniku - příčině. 
Prostředí se pak stává výzvou, která je uchopena mechanismy moderní společnosti: právními systémy, institucemi, zmocňuje se jí i věda vystupující jako spolehlivé a legitimní vědění, o něž Ize opřít praktické aktivity. Poznatky o prostředí jsou postupně zahrnovány do všech oborů, spíše vždy ale jako to, co je nějak za jejich hranicemi, nikoli jako jim vlastní „předmět”. Je to pro ně externalita, kterou nelze opomíjet v zájmu dosažení reprodukovatelných výsledků, protože s odchylkami jí způsobenými je v realitě nutno stále více počítat. $V$ různých vědních oborech se diskutuje o tom, jak úvahy o prostředí „internalizovat", začlenit do sítě těmito obory popisovaných souvislostí tak, aby se základní vzorec kauzálních souvislostí jinak nastavil, ve svém základu však nezměnil (Jamieson, 2003).

Současně se ale vynořují pochybnosti, zda to je plně možné: v environmentální problematice často hrají důležitou roli vztahy a vlastnosti, které byly již předtím reduktivním, objektivizujícím postupem vyloučeny. Je tak možné, že pozornost věnovaná prostředí se s př́snou objektivitou nějakým způsobem vylučuje. Dotyčná stránka skutečnosti by pak byla (vědeckému) poznání těžko přístupná a znamenalo by to také, že při úsilí o její pochopení je třeba usilovat o proměnu současného způsobu myšlení, samotné racionality. To potvrzuje například Gonzáles-Gaudiano (2004), který zpochybňuje ontologickou povahu znalostí běžného typu ve vztahu ke komplexní povaze environmentálních problémů; ty poznatky, které máme k dispozici, pokládá za "reziduum", bez něhož se sice momentálně neobejdeme, ale které musí být do budoucna transformováno.

Po environmentálním vzdělání se pak často požaduje rozchod se vzděláním klasickým, revize základních východisek, podstaty a povahy dílčího poznatku - celková proměna epistemologického pole. Dosavadní, dostupné, kognitivně založené přístupy k prostředí se stávají předmětem kritiky, protože neodpovídají povaze prostředí a přiměřenému způsobu nakládání s ním.

\section{Odraz proměn v environmentálním vzdělání}

V tuto chvíli je třeba stručně zrekapitulovat, $v$ jaké situaci je environmentální vzdělání $v$ současné době, jak je popisováno, kategorizováno atd. Zvláštní charakter prostředí a vztahů $v$ něm založených má na jeho podobu zásadní vliv, s nímž se různými způsoby (po svém) vyrovnává. Rozvíjí se ve třech okruzích, jak je z existujících směrů a konkrétních programů environmentálního vzdělání abstrahuje Palmer (1998):

1. Vzdělání O prostředí - jde o základní znalosti a porozumění prostředí; cíle jsou kognitivní povahy, mají vést k hromadění informací;

2. Vzdělání PRO prostředí - zdůrazňuje rozvíjení informovaného zájmu o prostředí; vzdělávací cíle směřují k vytváření hodnot, schopnosti realizovat praktické akce;

3. Vzdělání $V$ nebo SKRZE prostředí - zahrnuje přímou zkušenost, která je jedním z předpokladů vzniku poznatků a porozumění.

Tyto součásti (a zdroje) environmentálního vzdělání jsou na sobě víceméně nezávislé (viz obr. Tři východiska a součásti EV In Dlouhá, 2006); průniky jednotlivých sfér jsou možné, znamená to však spíše, že existují vedle sebe (oblasti průniku Palmer podrobně nepopisuje). Naopak, jednotlivé okruhy se vůči sobě vymezují:

Znalosti o prostředí vycházejí z předmětného uchopení skutečnosti, zabývají se objekty, nezávislými na okolnostech svého výskytu či př́stupu a vlastnostech pozorovatele. Jsou mimo prostředí a hodnotově indiferentní. Kognitivně orientovaná součást environmentálního vzdělání tak mưže být stejně abstraktní, jako kterákoli technická disciplina. Běžně se soudí, že využitím vědeckého popisu "prostředí" se vzdělání oněm řadí mezi technocentrické přístupy a ideologie; ty se potom zaměřují na 
environmentální management. Samotné vzdělání se pak stává neutrálním, instrumentálním procesem, kde na straně prostředí se objevují environmentální zákonitosti, procesy a problémy, na straně učení jsou fakta, koncepty, zobecnění. Tyto prístupy se ještě dále dělí z pohledu pedagogiky:

Je rozlišována konzervativní forma vzdělání o prostředí, která zdůrazňuje neoklasické vzdělávací hodnoty, vztah učení k praxi. Je zaměřena na přírodní vědy; obsah a metody výuky jsou založeny na technické racionalitě. Klíčový význam při řešení environmentálních problémů je přikládán úloze vědy a technologie.

Druhou kategorií jsou tzv. liberálně/progresivně založené pedagogické přístupy, které zdůrazňují rozvoj myšlení, osobnosti. Jejich metodou je problémově orientované učení, které má přivést studenty k využití oborových přístupů; někdy je zapojeno multidisciplinární myšlení.

Tento prístup jako celek však nepřikládá význam lidskému faktoru a podává depolitizovaný a dehumanizovaný obraz světa. Nejsou uvažovány sociální kontexty; strukturu znalostí často určují osnovy, environmentální témata se objevují bud' $v$ jednotlivých předmětech, nebo $v$ multidisciplinární perspektivě nezbytné při řešení problémů.

Vzdělání PRO prostředí přináší posun pozornosti směrem $\mathrm{k}$ dekonstrukci dominantních rámců. Takové vzdělání zahrnuje informovanost, která však není cílem - tím je aktivní zájem o kvalitu lidského života a prostředí. Objevuje se zde sociálně kritický prvek, pozornost je věnována skrytému kurikulu a hovoří se o kritické pedagogice (Fien, 2004).

Vzdělání V nebo SKRZE prostředí většinou prosazující ekologický determinismus, je kritizováno jako naivní, usilující o proměnu společnosti podle vzoru prírodních zákonitostí, a tedy $v$ nejlepším případě romantické, v nejhorším pak zcela reakcionářské (Fien, 2004). Neposkytuje nástroje pro praktické pừsobení a je obecně přijímáno jen jako zdroj přímé zkušenosti, materiál pro zkoumání a objevy, základ pro vytváření poznatků.

Tyto různorodé přístupy Ize stěží kombinovat, jejich spojení není organické - znamená spíše, že existují vedle sebe. Vědění, kterého jsme schopni dosáhnout, se $\mathrm{s}$ povahou prostředí míjí, není adekvátní ani $v$ oblasti praktických problémů $\mathrm{s}$ ním spojených, jejich předcházení či „řešení". Ani všechny poznatky o prostředí dohromady neumožní být $v$ souladu $s$ ním, bytostně prožívat vztahy, které jsou v něm založeny. Na druhé straně existenciální souznění s prírodou, prostředím je považováno za zradu na racionalitě, která člověka vede $k$ pasivitě, zřeknutí se specificky lidských možností rozhodování a jednání.

Určitým společným jmenovatelem, smyslem environmentálního vzdělání by měl být návrat z abstraktního světa teorií do zpřítomněné skutečnosti. Tato osobní angažovanost je však chápána nejednoznačně, vždy jinak.

\section{(Epistemologické) problémy vzdělání O prostředí}

V souladu s výše uvedenými úvahami se obecně soudí, že kognitivní stránku environmentálního vzdělání je možné rozvíjet „zvlášt", jednotlivé přístupy pak skládat dohromady. V tomto pohledu však poznatky o prostředí se vlastně "shodují" se znalostmi oborovými. Bývají definovány například jako příroda, vliv lidských činností na prostředí; konflikty, jejichž př́činou jsou lidské aktivity; další praktické znalosti z oblasti politiky atd. Zahrnují se sem následující (často vzájemně propojené) okruhy toho, co je jinde předmětem systematického poznání: klima, pưda (horniny a minerály), voda, materiály a zdroje, energie, rostliny a zvířata, lidé a jejich společenství, technologie a svět práce (Palmer, 1998). Otázka je, proč s rưznorodými informacemi o př́rodě i společnosti nevystačíme tak, jak je nám věda předkládá - tedy v jejich oborové podobě? 
Hlavním z důvodů, proč čistě oborový přístup nedostačuje, je samotná povaha skutečnosti: její komplexita, provázanost a dynamická podstata probíhajících dějů, princip sebe-organizace (autopoiesis) atd. Tyto stránky se pokoušela zachytit systémová teorie, která od svého počátku pronikala do všech oblastí vědy, hledala jejich univerzální "metodologickou kostru", novou půdu pro interdisciplinární př́stup. Její uplatnění $\checkmark$ různých oborech je dodnes rozsáhlé a také její aplikace $v$ rámci ekologie je široká. Systémová teorie poskytla podklad pro to, aby se ekologie mohla stát všeobecně použitelnou metodou - na tomto základě se pak "ekologizovaly" nejen prírodní, ale i společenské vědy.

Dnes se zdá, že univerzalistická perspektiva, kterou takový pohled poskytuje, vede $\checkmark$ praxi $\mathrm{k}$ hluboce esencialistickým př́stupům (hledání univerzálních pravd, jež jsou platné mimo historické souvislosti a $v$ různých kontextech, hledání jednotného světového uspořádání a transcendentní lidské bytosti, která na konci své cesty bude zbavena svých problémů, a především všezahrnujícího systému vědění, které vystihne konstitutivní povahu světa) - což je předmětem zásadní kritiky. V praxi pak takové "holistické" koncepty (ve kterých každý celek degeneruje na systém ovládaný pravidly systémových teorií) bývají kritizovány jako ve svých důsledcích totalitární, nevyhnutelně umrtvující všechny možnosti celospolečenského dialogu (Keulartz, 1998, 2005).

Přírodní, ale i technické a sociální systémy jsou $v$ současné době pokládány stále více nikoli za stabilní, založené na rovnovážných stavech, ale spíše dynamické, proměnlivé ve vzájemně se překrývajících časových a prostorových měřítcích. Evoluci těchto komplexních prírodních a sociálních systémů charakterizuje nejistota a $v$ některých př́padech chaos. Téma kontroly procesů, které se v nich odehrávají, nabývá spíše formu otázky, než připuštění možnosti dobře definovaných, vědecky podložených zásahù. Obecně v současné době vzniká nedůvěra $\mathrm{k}$ "expertním řešením", protože ty rizika spiše generují. (Berkhout, Leach \& Scoones, 2003). Systémové teorie samotné se již také proměňují: bedlivou pozornost věnují významotvorným faktorům a také kontextu (situačnímu porozumění atd.) (Whitaker, 1995).

\section{Vzdělání PRO prostředí - konstruktivistická řešení}

Vzdělávací strategie se utvářejí vždy s ohledem na celkovou perspektivu vědění; vycházejí z již legitimizovaných forem poznání, nezabývají se způsobem geneze dílčích poznatků. Usilují $\mathrm{o}$ objektivitu, $v$ mnohosti rủznorodých pohledů ale ztrácí naději na univerzální náhled, jednotnou metodu (viz výše). Skutečnost se rozpadá do mnoha různých, často vzájemně nesouvisejících oborů zkušenosti, ze kterých Ize jen stěží poskládat jakkoli smysluplný "obraz světa". Jak vyřešit tento problém? Vzdělání vychází z ustálených, obecně príjatých pojmů, definic a faktů, hlubší úvahy ontologické jsou daleko za obzorem pedagogických př́stupů, mimo jejich sféru zájmu a kompetence - $s$ radikálními změnami na úrovni pojmu či významotvorného textu, tedy $v$ oblasti ( $v$ přeneseném smyslu slova) sémantické, syntaktické, tak nelze počítat. Je ale možné utvářet skladbu celého „příběhu vzdělanosti”, re-konstruovat mozaiku vědění přeskupením jejích základních prvků.

Rámce (prakticky orientované či hodnotově založené) pro nakládání s poznatky vychází z vědění, jehož povaha je víceméně filosofická a aplikace jsou rázu etického. ${ }^{1}$

\footnotetext{
1 Tato předem zamýšlená struktura, rámec uspořádání je ve smyslu Kantovy epistemologie řízen regulativní ideou (viz Rauch, 2004). Může jí být např. koncept trvalé udržitelnosti, který se pak stává základem tvorby tzv. "kritického kurikula” založeného na re-konstrukci (dominantního) sociálního paradigmatu. Je třeba ovšem dát pozor na to, že tato regulativní idea nabývá různou podobu v závislosti na historických okolnostech, kulturním prostředí atd. výše zmíněným pravidlům by měla odpovídat povaha environmentální gramotnosti - nemá být imprintingem konzistentních východisek, a tedy ani pevným souborem znalostí, jež sugerují univerzální hodnotové rámce. Musíme si být také vědomi toho, že vhodné odpovědi a řešení se liší podle kulturního kontextu; tyto odpovědi se mění spolu s tím, jak rostou naše zkušenosti.
} 
Celek vědění totiž odráží širší oblast zkušenosti, než kterou je schopna zprostředkovat věda, a dokonce i než samotné poznání - netýká se jednoho určitého druhu výpovědí, například výpovědí kognitivních, s vyloučením ostatních. Ve vědění jsou přítomny představy dovednosti, správného chování, umění naslouchat atd. Vědění je vše, co umožňuje "dobré" výkony nejen v souvislosti s poznáním, ale i rozhodováním, hodnocením, přetvářením (Lyotard, 1993). Všechny „neobjektivní" okruhy vědění (jež nejsou zcela vytlačeny ani tehdy, když jim nepřikládáme důležitost) se pak stávají součástí širokých konceptů, kterými organizujeme skutečnost, okolní svět. Pokud však tato (filozofická) východiska systematicky nereflektujeme, nerozvíjíme, mohou být různé rámce, ve kterých se pak i prakticky pohybujeme, založeny na falešných předpokladech, mohou se ukázat jako naivní nebo vzájemně neslučitelné; a vést k nepředpokládaným a nepříznivým důsledkům.

Debaty o environmentálním vzdělání jsou tak často zaměřené na to, jak vhodně zkombinovat různé, již existující součásti či elementy a na tomto základě uspořádat dostupné informace (to posouvá problém do roviny strukturalistické). Jednotlivé oborové diskursy se stávají prvky stavby poznání, jež vưči sobě navzájem vystupují jako víceméně uzavřené entity. ${ }^{2}$ Takto pak jejich vzájemné vztahy (a také principy jejich organizace do určitých celků) podléhají pravidlům "řečových her", jež zajištují nezbytnou diverzitu pohledů a brání utváření "jednotného světového názoru". "Řečové hry" jsou nevyhnutelným předpokladem pro zachování plurality pohledů, neumožňují hledání univerzálního smyslu. ${ }^{3}$

Aspekty „prostředí”, které ukazují na jeho komplexní a kontextuální povahu, se ukazují v souvislostech reorganizovaného učiva, uspořádaného do nově koncipovaných struktur a systémů. Tyto rámce nejenže člení a zpřehledňují dostupné poznání, umožňují je systematicky rozšiřovat atd., ale často mu dodávají nový, implicitní smysl.

\section{Vzdělání V prostředí}

Snahy o změnu pohledu na skutečnost, které by vedly k odlišným způsobům nakládání s ní, mohou být vedeny nejen zájmem praktickým, ale také úsilím o pochopení současného stavu, východisek myšlení, a nově otevíraných myšlenkových prostorů. Takové přístupy se soustřed’ují kolem pojmu „prostředí", které nelze vždy uchopit tradičními metodami, a to ani ve výuce.

„Prostředí" tak, jak je běžně chápáno (přesnější definice viz Dlouhá, 2006), zahrnuje věci a jevy zcela konkrétní, jako je půda, voda, vzduch, další organismy. Environmentální discipliny však neusilují o popis těchto jednotlivých (a jedinečných) složek $v$ jejich svébytnosti, nezajímají se o jejich „podstatu”, jež vychází z nich samých a vymezuje je vưči skutečnostem jiným, zakládá je pojmově. Samo „prostředí totiž není jen souhrnem svých "složek", věcí a jevů „zpředmětněných" pro objektivní vědecké pozorování.

Způsob, jakým k věci či jevu (složce prostředí) přistupujeme, jestliže jej do kategorie "prostředí" řadíme, významně souvisí s tím, jaký kontext pro existenci jiných věcí a jevư sám vytváŕí. Zpưsob existence "v prostředí" pak znamená nejen svůj vztah k prostředí projevovat, být jím spoluvytvářen, ale také se na tvorbě kontextu pro jiná existující jsoucna podílet.

\footnotetext{
${ }^{2}$ Vnitřní souvislosti diskursu je možné „zvenku" nahlížet pouze v omezené míře, do jím utvářeného kontextu nelze zasahovat, protože jen on generuje význam a zde tedy vznikají také zvenčí viditelné produkty, poznatky - tak tomu je alespoň v objektivním pohledu na skutečnost.

3 Antiesencialistický aparát se často zabývá epistemologickými problémy - polemizuje např́íklad s východisky př́rodních věd či ekologie, které do environmentálně založeného diskursu vnáší určitou formu „objektivity" a pojetí subjektu (Gonzáles-Gaudiano, s.120 - 127).
} 
Vztahovost, jako primární vlastnost prostředí, spoluurčuje podobu věcí a jevů. Je uchopitelná nikoli skrze jejich trvalé atributy (definující věc o sobě), ale $v$ proměnlivosti (pro-jevech jakožto výslednicích vztahů). Pokud nám jde právě o podoby té které skutečnosti ovlivněné faktory, které působí za jejími hranicemi, pak výše zmíněné vlivy již nemohou být odsunuty za horizont uvažování - jde nám právě o jejich podíl na utváření skutečnosti. V tomto zájmu již jednotlivé nenese plnohodnotný smysl samo o sobě, zabýváme se jím v souvislosti s jinými jsoucny, v "komplexitě" jeho vztahů ke jsoucnům dalším.

Environmentálně orientovaná pozornost se soustřed’uje na ty vlastnosti věcí a jevů, jež jsou relevantní (utvářené či pochopitelné) v daném kontextu; nakonec však odkrývá každý způsob popisu jakožto kontextuální. To znamená, že podoby a významy souvisejí s určitým typem kontextu (či diskursu), v rámci kterého je daný jev popisován. Vzhledem k „prostředí" se tedy zájem nesoustřed'uje na jednotlivé skutečnosti, které Ize spolehlivě vymezit, jednoznačně popsat a předvídatelně s nimi nakládat, kontrolovat je. Jestliže jde o vzájemné vztahy mezi přirozeně existujícími entitami, pak tyto vztahy ani kontrolovatelné nejsou (kontrola je jiným typem vztahu, který mění povahu vztahu původního).

Předchozí úvahy znamenají, že pokud se teoreticky či prakticky zajímáme o „prostředí", přestávají být důležité jeho „prvky”; na významu nabývají naopak vztahy mezi nimi, či jakési pole těchto vztahů, kontext existence. Takto se mění celková perspektiva pohledu na skutečnost - vlastnosti již nejsou hlavním či náhodným atributem věcí či jevů o sobě, ale závisí na způsobu, jak ( $v$ jakém kontextu) tyto jsou nebo se nám ukazují. Jestliže jsme dosud mluvili o povaze věci jako např. funkci jejího vnitřního uspořádání, můžeme ted' hovořit o závislosti opačné. Podoba toho, co je, se modifikuje pưsobením vnějších vztahů, prostředí. Skutečnost již není souborem objektivně vymezených věcí a jevů, jejichž podstata je trvalá a proměnlivost funkcí vnějších zásahů; Ize na ni nahližet prizmatem kontextu, který objektivizovat nelze, který však vytváří prostor spoluúčasti a také srozumění. Pro tento úhel pohledu platí, že nemůže být objektivizován: akontextuální (vždy stejně, nezávisle, nezúčastněně reprodukovatelný) pohled na kontext možný není.

Samotná environmentální problematika do jisté míry opodstatňuje pozornost, kterou je třeba "kontextu" věnovat. Metodou "pokusu a omylu” stále více vychází najevo, že snahy o zachování konkrétních entit jsou neúspěšné, pokud jsou zásadním způsobem narušeny jejich vztahy k okolí. Dále také metody "ochrany přírodních systémü" svou malou účinností dokumentují, že nejde pouze o zachování nejdůležitějších funkcí jednotlivých prvků a podporu hladkého průběhu dějů vycházejících z energetických závislostí mezi nimi. $\checkmark$ obou př́padech usilujeme o to, abychom danou skutečnost - poznanou $v$ její redukované podobě, s ohledem na možnosti vlastní intervence do ní - podpořili $v$ jí příslušejícím způsobu bytí. Máme-li ji uchovat tak, jak (o sobě) je, musíme pečovat o to, co je $v$ ní "navíc" oproti obrazu, který jsme si o ní (reduktivními postupy) vytvořili: zachovat možnost vztahů jako takovou.

\section{Závěr:}

Popis environmentálního vzdělání ve zmíněných třech okruzích odkazuje k tradičnímu dělení ekologie na "plytkou” a "hlubinnou” (Kohák, 1996, Činčera, 2001). Hlubinné směry se i zde považují za zcela nepraktické, zříkající se možnosti jakkoli zasahovat do běhu světa. Ve své pưvodní podobě jsou ale pouhým korelátem systémových disciplin, jež veškeré vztahy převádějí na toky energií a informací. Odklon od (převládajícího typu) racionality, který prosazují, vychází ze zklamání nad praktickým 
neúspěchem systémových teorií a sozologických projektů 4 na nich založených; Ize jej považovat hledání alternativ, jež by umožnily soulad lidské existence se vztahy založenými v prostředí. Pocit, že se vytrácí základní naladění na přírodu, a že se člověk vzdaluje jejímu životodárnému působení, však již nelze považovat za pouhý emocionální „úlet" - tento dojem se potvrzuje fyzicky $v$ obdobích života, která jsou pưvodním souladem ovládána (dětství a především vše související se zrozením člověka).

Potřeba znovu promyslet vztahy $v$ prostředí založené a náš podíl na nich se ukazuje i prakticky, znovu s objevením se konceptu trvale udržitelného rozvoje. Pohled do budoucna, otevření prostoru pro aktivní působení člověka na prostředí jako nejednoznačné, nedeterminované, naopak diskuzi podléhající možnosti, klade důraznou otázku po tom, co má být zachováno. Jsou to pouhé předpoklady, "výrobní zdroje"? Jde o nějaké konkrétní entity, živočišné a rostlinné druhy?

Stále více se ukazuje, že to vše nestačí a je třeba vzít v úvahu prostředí jako celek, pole vztahů, kontext existence. $\mathrm{V}$ tomto ohledu se $\mathrm{k}$ prostředí stále vracíme jako k horizontu myšlení, kterého sice nelze dosáhnout, zpředmětnit jej pro objektivní pohled a nakládat s ním obvyklými způsoby; který je ale důležitou konstitutivní součástí skutečnosti, a v určitém ohledu svorníkem její celistvosti.

\section{Literatura:}

- ALACAMO, J. et al., (2003) Ecosystems and Human Well Being: a Framework for Assessment. In Millenium Ecosystem Assessment. Washington: Island Press.

- Atkinson, E. (2000). The Promise of Uncertainty: Education, Postmodernism and the Politics of Possibility. International Studies in Sociology of Education, 10(1), 81-99.

- Barnett, R. (2000). Supercomplexity and the Curriculum. Studies in Higher Education, 25(3), 255-265. Retrieved from http://www.tandfonline.com/doi/abs/10.1080/713696156 http://dx.doi.org/10.1080/713696156

- BERKHOUT, F., LEACH, M., SCOONES, I. (eds.), (2003). Negotiating Environmental Change: New Perspectives From Social Science.. : Edward Elgar.

- Činčera, J. (2001). Člověk a životní prostředí (humanistická environmentalistika). : Vyšší odborná škola informačních služeb v Praze. Retrieved from http://info.sks.cz/users/cn/zp

- Dlouhá, J. . EnviWiki. Internetová encyklopedie věnovaná vzdělávání zaměřenému na prostredí. .

- Fien, J. (2004) Education for the environment: critical theorising and environmental education. In S. Gough \& W. Scott (Eds.), Key Issues in Sustainable Development and Learning: A Critical Review (pp. 120-127). .

- Gonzáles-Gaudiano, E. (2004) Complexity in environmental education. In S. Gough \& W. Scott (Eds.), Key Issues in Sustainable Development and Learning: A Critical Review (pp. 120-127). London/New York: RoutledgeFalmer.

\footnotetext{
4 Termín sozologie znamená vědecky fundovanou ochranu přírody; využívá řeckého základu "sozó", který znamená "uchovávat, udržovat, spasit" ${ }^{4}$ (LACINA, J.: Sozologické aplikace geobiocenologie, dostupné z WWW: <www.geogr.muni.cz/cgs/source/rel-kraj/lac.doc>)
} 
- Gough, S. (ed.), SCOTT, W. (ed), (2004). Key Issues in Sustainable Development and Learning: A Critical Review. Falmer Press; 1 edition. ISBN. London ; Routledge Falmer, 2004: Falmer Press.

- Jamieson, D. A. L. E. (2003). A Companion to Environmental Philosophy. Malden, Mass: Blackwell Publishing Ltd. Retrieved from http://doi.wiley.com/10.1111/b.9781405106597.2003.x http://dx.doi.org/10.1111/b.9781405106597.2003.x

- Keulartz, J. (1998). Struggle for nature: A critique of radical ecology. London: Routledge.

- Keulartz, J. (2005) Boundary-Work - The Tension Between Diversity and Sustainability., Contribution to the Prague Conference of the Forum of University Teachers. In Dlouhá, J., Dlouhý, J. (Ed.), Co znamená udržitelnost pro univerzity? (pp. 44-54). : Univerzita Karlova v Praze, Centrum pro otázky životního prostředí.

- KOHÁK, E. a kol., (1996). Závod s časem (texty z morální ekologie). Praha: MžP.

- Lyotard, J. F. (1993). O postmodernismu. Postmoderno vysvětlované dětem. Postmoderní situace. Praha: Filosofický ústav AV ČR.

- Palmer, J. A. (1998). Environmental Education in the 21st Century. Theory: Practise: Progress and Promise.. London: RoutledgeFalmer.

- Rauch, F. (2004) Education for sustainability: a regulative idea and trigger for innovation. In Gough, S., \& W. Scott (Eds.), In W. Key Issues in Sustainable Development and Learning: A Critical Review, 149 - 151. London/New York: RoutledgeFalmer.

- Whitaker, R. (1995). Self-Organization, Autopoiesis, and Enterprises.. . Retrieved from http://www.acm.org/sigs/sigois/auto/Main.html

\section{Recenzní posudky (souhrnná slovní hodnocení a doporučení)}

Pozn.: Recenzní posudky se týkají původní verze příspěvku.

\section{Recenzent 1:}

Jsem toho názoru, že příspěvek „Environmentální vzdělání - pokus o systematické pojmenování problému" by měl být publikován, protože kromě toho, že přinejmenším uspokojivě splňuje všechny předepsané náležitosti, představuje, zdá se mi, velice originální, a přinejmenším u nás nový pohled na některé významné problémy environmentálního vzděl(áv)ání.

Za hlavní přednost textu považuji otevření nového pohledu na životní prostředí, jakožto určitou jaksi primárně dynamickou kontextualitu - pohledu, který je jednak svým způsobem paradigmatický, a jednak nepominutelný v praxi environmentálního vzdělávání, má-li být toto efektivní. Za hlavní nedostatek příspěvku považuji jeho poněkud těžký styl, který by mohl některé čtenáře odradit, což by byla velká škoda, nebot' témata, kterým se věnuje, jsou, dle mého názoru, zcela klíčová pro environmentalistiku jako celek.

Výzkumnou otázku, kterou př́spěvek klade - totiž otázku po epistemologickém, resp. obecně metodologickém zakotvení environmentalistiky - považuji, a to zvláště v českém prostředí, za nanejvýš relevantní.

Metodiku samotného př́spěvku považuji za uspokojivou, stejně jako formální úroveň sdělení. Závěry jsou poměrně jasné, otázka po jejich reprodukovatelnosti je u tohoto typu př́spěvku zřejmě irelevantní.

\section{Pavel Skála}




\section{Univerzita Karlova - Přírodovědecká fakulta}

Recenzent 2:

Doporučuji lépe promyslet a přesněji formulovat charakteristiku přístupu „v prostředí" - text není př́liš konzistentní.

\section{Bedřich Moldan}

Univerzita Karlova - Centrum pro otázky životního prostředí

Časopis Envigogika vydává Centrum pro otázky životního prostředí UK. Vývoj časopisu je podpořen projektem OP VK Mezioborová sít udržitelného rozvoje.

Více najdete na internetových stránkách projektu mosur.czp.cuni.cz
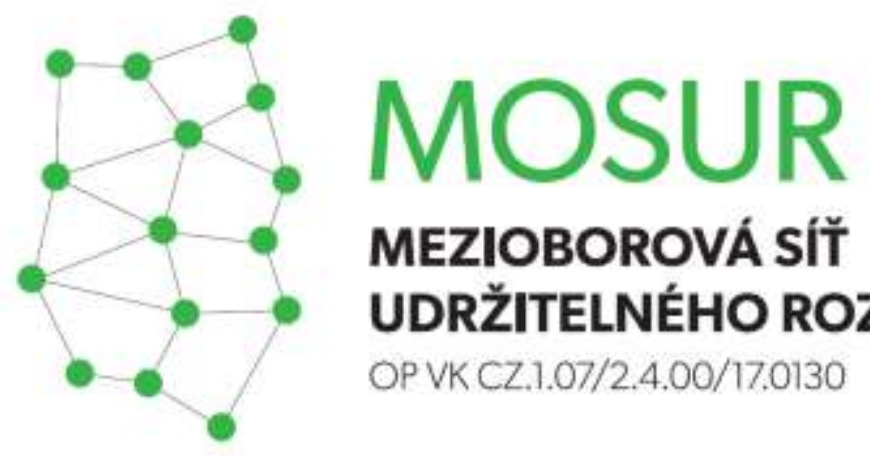

\section{MEZIOBOROVÁ SÍT} UDRŽITELNÉHO ROZVOJE

OPVKCZ.1.07/2.4.00/17.0130
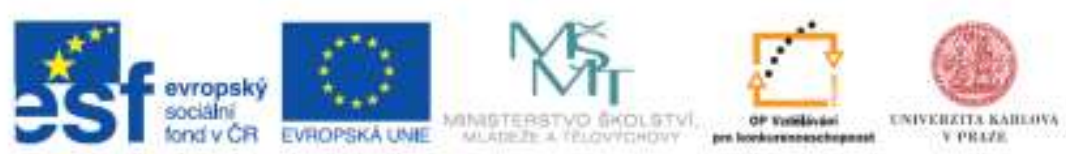

INVESTICE DO ROZVOUE VZDELAVANI 